\title{
Asesmen Perkembangan Anak Usia Dini Di PAUD MPA Daycare
}

\author{
Efiawati $^{1}$, Debibik Nabilatul Fauziyah ${ }^{2}$, Rina Syafrida ${ }^{3}$, Asmidar Parapat ${ }^{4}$ \\ $1,2,3$ Universitas Negeri Singaperbangsa Karawang, Indonesia \\ ${ }^{4}$ Universitas Pembangunan Panca Budi Medan, Indonesia \\ efiawati67@gmail.com
}

\begin{abstract}
Abstrak
Banyaknya pendidikan anak usia dini yang kurang mengetahui pentingnya asesmen pada aspek perkembangan anak menjadi salah satu alasan bagi penulis dalam melakukan penelitian. Asesmen aspek perkembangan inilah menjadi tolak ukur kemampuan ataupun bakat anak, yang akan berguna hingga dewasa. Untuk menambah wawasan tentang asesmen perkembangan anak di usia dini maka penulis mengadakan penelitian di PAUD MPA Daycare. Penggunaan asesmen di PAUD MPA Daycare untuk memberikan informasi kepada pendidik dan orang tua, sehingga orang tua dapat ikut serta membantu dalam pencapaian perkembangan anak secara optimal. Berbeda dengan penelitian sebelumnya pada penelitian ini ada enam aspek perkembangan yang dilakukan asesmen sehingga hasil dari penelitian ini menunjukan betapa pentingnya asesmen yang dilakukan secara menyeluruh. Penelitian ini menggunakan metode penelitian kualitatif dengan pengumpulan data melalui observasi dan wawancara. Dilihat dari hasil analisis data melalui observasi/pengamatan serta wawancara secara keseluruhan, pelaksanaan asesmen di PAUD MPA Daycare, Karawang di lakukan dengan baik sehingga dapat mendeteksi tingkat pencapaian perkembangan anak sesuai kurikulum pembelajaran 2013. Dari hasil penelitian ini dapat diketahui bahwa asesmen sangat dibutuhkan dalam suatu lembaga untuk penilaian perkembangan anak.

Kata kunci: perkembangan anak; asesmen; anak usia dini
\end{abstract}

\section{Evaluation Of Child Development In Early Childhood MPA Daycare}

\begin{abstract}
The number of early childhood education that is less aware of the importance of assessment on aspects of child development is one of the reasons for the author in conducting research. Aseries of aspects of development is a benchmark of children's abilities or talents, which will be useful until adulthood. To add insight into the assessment of child development at an early age, the authors conducted research at PAUD MPA Daycare. The use of assessments in PAUD MPA Daycare to provide information to educators and parents, so that parents can participate in helping in the achievement of optimal child development. In contrast toprevious research in this study there aresix aspects of development carried out by assessments so that the results of this study show how important assessments are done thoroughly. This research uses qualitative research methods with data collection through observation and interviews. Judging from the results of data analysis through observations / observations and interviews as a whole, the implementation of assessments at PAUD MPA Daycare, Karawang is done well so that it can detect the level of achievement of child development in accordance with the 2013 learning curriculum. From the results of this study it can be known that assessment is needed in an institution for assessment of child development.
\end{abstract}

Keyword: child development; assessment; early childhood 


\section{PENDAHULUAN}

Pendidikan Anak Usia dini adalah pendidikan non formal yang diselenggarakan oleh pemerintah. Seperti yang termaktub di Undang - Undang No. 20 tahun 2003 tentang Sistem Pendididkan Nasional pada pasal 1 ayat 14, menyatakan bahwa "Pendidikan Anak usia dini adalah suatu upaya yang di selenggarakan pemerintah dalam pembinaan terhadap anak usia dini dilakukan melalui pemberian stimulasi pendidikan dalam membantu pertumbuhan dan perkembangan jasmani dan rohani sehingga anak siap dalam memasuki pendidikan dasar (Khadijah \& Amelia, 2020). Pendidikan pada masa $0-6$ tahun sangat penting sebagai pondasi awal kehidupan anak. dengan memberikan rangsangan pendidikan yang tepat maka semua aspek - aspek perkambangan anak akan berkembangan secara optimal (Amalia, 2016). Demikian juga pertumbuhan jasmani anak akan terkontrol dengan baik melalui Deteksi Dini tumbuh kembang yang di lakukan sebulan sekali pemeriksaan melalui penimbangan berat badan, pengukuran tinggi badan dan lingkar kepala serta pemberian gizi seimbang pada anak (Wijaya Kuswanto \& Dinda Pratiwi, 2020).

Pertumbuhan dan perkembangan anak pada usia 3 tahun sampai 6 tahun adalah usia pada masa keemasan, dimana pada masa ini hampir seluruh aspek perkembangan anak berkembang secara cepat dan hebat. Pada masa usia 3 tahun - 6 tahun anak sedang penuh dengan aktifitas dan kreatifitasnya. Menurut Erick Erikson dalam jurnal (Ine Nirmala dan Feronica Eka Putri, 2015) mengatakan pada masa ini anak mulai dibentuknya sikap inisiatif versus rasa bersalah. Anak-anak yang dibesarkan dalam lingkungan pola asuh dan pendidikan yang baik, maka dapat membantu anak mengembangkan karakteristiknya sehingga anak lebih kreatif, antusias dalam bereksplorasi, bereksperimen, berimajinasi, dan berani mencoba halhal baru.

Anak usia dini merupakan usia yang istimewa sebab pada usia ini setiap anak akan memiliki ke unikan atau anak akan terlihat karakteristik yang khas. Hal ini berlandaskan dari teori Erik Erickson menyatakan bahwa anak prasekolah adalah pembelajar aktif berenergi, antusiasme, dan berimaginasi yang aktif (Sari, 2013). Setiap individu anak akan memiliki karakter yang berbeda, melalui stimulasi yang baik, anak akan berkembang secara optimal. Karateristik anak antara lain: anak memiliki rasa ingin tahu yang besar, suka berfantasi dan berimajinasi, memiliki sikap egosentris, memiliki daya konsentrasi yang pendek, suka bersosial, mudah berempati dan suka bergerak / bermain (Wiyani, 2019). Karakter inilah yan membuat setiap anak berbeda dan unik. Karakteristik anak terbentuk dari faktor genetik atau 
terbentuk dari faktor lingkungan. manfaat dari karakteristik anak dapat menentukan gaya belajar anak dan kecerdasan anak. Karakteristik anak akan berbeda sesuai tahapan usianya, sehingga karakteristik anak dapat dimengoptimalkan kegiatan pembelajaran.

Pengembangan aspek perkembangan anak usia dini ditetapkan di Undang-undang No. 137 tahun 2014, tentang Standar Tingkat pencapaian Perkembangan anak (Khadijah \& Amelia, 2020). Ditetapkan bahwa aspek-aspek perkembangan anak di bagi dalam enam aspek perkembangan, yaitu: aspek perkembangan nilai agama dan moral, aspek perkembangan fisik motorik, aspek perkembangan kognitif, aspek perkembangan bahasa, aspek perkembangan sosial emosional dan aspek perkembangan seni. Aspek-aspek perkembangan anak terlihat minat dan bakatnya dalam belajar. Sehingga memudahkan pendidik dalam mengembangkan kecerdasannya secara optimal. Semua aspek - aspek perkembangan harus terstimulus dengan baik, sehingga berkembang dengan optimal. Namun dalam kegiatan pembelajaran anak yang bertujuan untuk mengoptimalkan perkembangan kecerdasannya pendidik tidak boleh mengindahakan akan fitrah anak yaitu bermain. Pembelajaran harus dalam batas mengenalkan dan dalam situasi yang menyenangkan. Anak harus bahagia dalam belajarnya.

Aspek kemampuan nilai agama dan moral adalah kemampuan anak dalam bersikap dan berperilaku sesuai dengan aturan-aturan agama yang dianut. Aspek ini yang mengenalkan tentang adanya Tuhan, mengenal ciptaan - ciptaan Tuhan, dan tuntunan tingkah laku dan perbuatan yang baik terhadap sesama (Saripudin \& Awelas, 2020). Aspek perkembangan fisik motorik pada usia dini terbagi menjadi tiga bagian yaitu motorik kasar, motorik halus, dan kemampuan anak dalam menjaga kebersihan diri dan lingkungannya (Nugraha, 2015). Keterampilan motorik kasar dapat diartikan sebagai keterampilan dalam menggerakkan seluruh otot-otot anggota geraknya, seperti gerakan perpindahan tempat yang dilakukan otot kaki, gerakan kelenturan, serta gerakan keseimbangan (Syafrida et al., 2020; Yuningsih \& Hasanah, 2018). Motorik kasar yaitu gerak dasar pada seperti anak bergerak melompat, berjinjit, berlari, memutar (Wiresti, 2021). Motorik halus adalah kemampuan anak dalam mengkoordinasikan otot tangan dan mata, Seperti meronce, menulis, menuang, melipat, menggunting, meremas, menggenggam dan menggambar (Erlianda et al., 2019).

Aspek perkembangan kognitif yaitu kemampuan anak yang berhubungan dengan kemampuan berfikir. Aspek ini berbentuk: 1) kemampuanan anak dalam memecahkan masalah sederhana yang ditemui dalam kehidupannya atau ingin mencoba hal baru, 2) Kemampuan anak dalam berpikir logis seperti klasifikasi benda, mengenal pola, berani 
berinisiatif, mampu mengenal sebab akibat, 3) Kemampuan anak berpikir simbolik yaitu kemampuan mengenal, menyebutkan angka, huruf dan mengenal konsep bilangan. Serta dapat mempresentasikan berbagai benda dan imajinasinya (Nur et al., 2020). Aspek kemampuan Bahasa merupakan keterampilan berbicara anak, yang meliputi kemampuan bahasa reseptif yaitu kemampuan dalam memahami perintah, kemampuan bahasa ekspresif yaitu kemampuan dalam mengungkapkan bahasa baik secara verbal maupun nonverbal, dan mengenal keaksaraan yaitu kemampuan mengenal huruf dan angka (Prihanjani et al., 2017). Aspek sosial emosional yaitu kemampuan anak dalam mengenal dirinya sendiri dan cara berinteraksi dengan orang lain. Dalam aspek perkembangan anak dapat memahami emosi yang keluar dari dirinya, mampu mengungkapkannya. Anak dapat berinteraksi dengan teman sebaya, teman labih tua, teman lebih muda, orang tua dan guru. Aspek perkembangan seni merupakan kemampuan anak dalam berperilaku mampu menghargai keindahan, hasil karya diri sendiri maupun orang lain, alam dan lingkungan. Anak mampu mengenal karya dan kegiatan seni, serta dapat melakukan berbagai aktifitas karya seni menggunakan media. Aspek-aspek perkembangan dapat terlihat dari hasil asesmen yang dilakukan oleh pendidik.

Asesmen perkembangan yaitu proses kegiatan untuk mengumpulkan, menyatukan dan menginterpretasikan data atau informasi mengenai perkembangan serta hasil belajar anak usia dini (Jatmiko et al., 2020). Menurut EJohnson menyatakan bahwa Asesmen merupakan mengumpulkan, menyaring dan mengartikan data informasi untuk mengambil suatu keputusan (Astuti et al., 2012). Seperti yang termaktub dalam Peraturan Menteri Pendidikan dan Budaya No. 146 Tahun 2014 menerangkan asesmen merupakan salah satu proses pengolahan data informasi, pengumpulan hasil perkembangan anak untuk mengukur tingkat pencapaian perkembangan anak dalam kegiatan proses pembelajaran(Khadijah \& Amelia, 2020). Dari teori teori diatas dapat di tarik kesimpulan bahwa asesmen adalah pengumpulan penyatuan dan mengartikan data informasi untuk mengukur tingkat pencapaian perkembangan anak, dan keberhasilan dari program kegiatan pembelajaran.

Asesmen di dalam lembaga digunakan untuk mengukur tingkat perkembangan anak dan sebagai tolak ukur keberhasilan dari program kegiatan pembelajaran. Assessment dilakaukan secara berkala dan berkisinambungan sehingga dari hasil-hasil assessment tersebut dapat ditarik kesimpulan sejauh mana tingkat perkembangan anak. Di PAUD MPA Daycare melakukan beberapa assessment dalam menilai perkembangan anak, sehingga guru dapat menilai apakah anak sudah berkembang sesuai dengan standar tingkat pencapaian 
perkembangan anak, dari penilaian tersebut guru dapat melakukan evaluasi serta menindaklanjuti apabila terdapat siswa yang belum berkembang. Berbeda dengan penelitianpenelitiann sebelumnya yang melakukan asesmen satu aspek perkembangan, pada penelitian ini ada enam aspek perkembangan yang dilakukan asesmen sehingga hasil dari penelitian ini dapat menunjukan betapa pentingnya asesmen yang dilakukan secara menyeluruh. Berdasarkan dari latar belakang diatas, penelitian ini diharapkan dapat memberikan informasi bagi guru dan orang tua tentang pentingnya asesmen bagi perkembangan anak.

\section{METODE PENELITIAN}

Metode yang digunakan dalam penelitian ini adalah metode penelitian kualitatif. Sugiyono berpendapat bahwa penelitian kualitatif yaitu pendekatan yang digunakan dalam penelitian untuk mengetahui dan menggambarkan kejadian yang nyata dari objek penelitian supaya mudah dalam memperoleh data yang konkret dan kondisi objek yang alamiah(Adhimah, 2020). Pada penelitian ini dilakukan di PAUD MPA Daycare, yang berlokasi di Karawang. Pemilihan PAUD MPA Daycare sebagai tempat penelitian untuk mengetahui keberhasilan penggunaan program penilaian yang digunakan di sekolah PAUD MPA Daycare. Adapun subjek dari penelitian ini adalah siswa yang mewakili usia 3tahun, 4 tahun, 5,7 tahun. Dengan objek penelitian aspek - aspek perkembangan anak pada siswa yang ada di PAUD MPA Daycare Karawang.

Perolehan data dan informasi dalam penelitian, menggunakan: Metode observasi atau pengamatan yakni data-data dikumpulkan melalui cara melihat, mengamati serta menganalisa objek penelitian. Metode wawancara yakni data-data dikumpulkan melalui pengajuan Tanya jawab kepada anak, pendidik, dan orangtua. Metode pustaka yaitu untuk pengumpulan teoriteori untuk digunakan sebagai landasan teori dalam pembahasan masalah. Dokumentasi yakni peneliti mengambil dokumentasi berupa foto dan video aktivitas anak dalam melakukan kegiatan pembelajaran, dan portofolio. Penelitian ini dilakukan melalui cara mengikuti proses kegiatan pembelajaran di PAUD MPA Daycare dari awal sampai akhir.

Peneliti perlu menganalisa informasi tentang aspek-aspek perkembangan anak yang telah dikumpulkan. Proses analisa penting dalam menyeleksi fakta - fakta yang relevan dari sejumlah kegiatan yang dilakukan anak. Tahapan analisa memungkinkan peneliti melakukan 
semacam asesmen tentang aspek perkembangan dan perilaku anak yang digambarkan dalam berbagai format seperti ceklis dan wawancara.

\section{HASIL DAN PEMBAHASAN}

\section{A. Hasil}

Pada pelaksanaan penelitian tentang asesmen harus merencanakan beberapa rencana supaya observasi berjalan dengan lancar dan hasil dari observasi cukup valid, di antara nya: 1) peneliti merencanakan kegiatan yang akan di gunakan untuk observasi, seperti RPPH pada waktu pelaksanaan 2) Menentukan 3 anak yang akan di observasi untuk mewakili kelasnya, KW (PG), RZ (TK A), dan RF (TK B). 3) peneliti mengumpulkan identitas yang akan di observasi. 4) penulis mengamati dan mencatat semua kegiatan anak yang akan di observasi. 5) melakukan wawancara baik terhadap anak, guru dan orangtua. Menurut Zahro (2015) penelitian dibagi menjadi beberapa tahap, yaitu tahap yang pertama yaitu merencanakan pembelajaran, tahap kedua pelaksanaana atau pencatatan proses pembelajaran, pengolahan hasil kegiatan belajar, diarsipkan kemudian pelaporan (Damayanti et al., 2018). Berdasarkan dari teori diatas maka hasil penelitian dapat di gambarkan sebagai berikut:

Penelitian di PAUD MPA Daycare dimulai dengan menetukan waktu observasi, memilih anak berdasarkan usianya, yang mejadi objek dalam penelitian dan merencanakan pembelajaran. Menyiapkan rencana pelaksanaan pembelajaran harian. Menentukan indikator penilaian dari aspek perkembangan yang di observasi berdasarkan Peraturan Menteri Pendidikan Nasonal No. 146 tahun 2014 tentang Standar Pelaksanaan Pendidikan Anak, Pelaksanaan observasi di PAUD MPA Daycare dalam kegiatan belajar dimulai dari pukul 08.00 - 11.00 WIB. Kegiatan pembelajaran di PAUD MPA Daycare sebagai berikut:

\section{a. Kegiatan Jurnal}

Setelah masuk dikelas dan duduk menggunakan kursi dan meja, anak-anak membaca doa memulai belajar, hafalan Al Quran surat pendek, hadits. Guru melakukan absen siswa melalui nyanyian. Menerangkan tema pembelajaran sebagai pijakan jurnal. Membagikan kertas secara estafet kemudian kegiatan jurnal dimulai. Siswa menggambar sesuai kemampuan menuangkan imjinasinya ke dalam kertas kosong untuk menstimulus kognitif dan kemampuan awal menulis. Guru memberi kesempatan siswa untuk menulis 
identitas/nama di sudut kertas jurnal. Setelah selesai membuat jurnal anak akan melaporkan hasil jurnal dengan cara menceritakan hasil gambarnya, sehingga terstimulasi perkembangan bahasanya.

Asesmen yang dilakukan guru pada kegiatan jurnal yaitu berkaitan dengan kemampuan anak pada tahapan meggambar dan menulisnya. Ada 12 tahapan dalam kemampuan menggambar anak: 1) coretan awal menggambar secara acak, 2) coretan terarah, coretan berulang adanya titik dan garis secara berulang-ulang, 3) muncul lingkaran-lingkaran kecil, 4) muncul gambar lingkaran besar/kepala besar, 5) menggambar kepala besar disertai dengan kaki dan tangan berupa garis., 6) menggambar kepala besar lengkap dengan kaki dan tanngan serta munculnya huruf-huruf mengambang/tidak beraturan, 7) gambar kepala besar dan batang tubuh,kaki dan tangan. Pada tahapan ini anak mulai belajar menulis keterangan gambar. 8) menggambar kepala besar disertai badan berbentuk segitiga dan kotak, 9) tahap ke 9 anak mulai menggambar rumah dengan bentuk sederhana, bunga dan kupu-kupu. 10) tahap ke 10 anak mulai dapat membedakan benda-benda yang ada di tanah dan langit, seperti menggambar rumah diatas tanah dan matahari diatas langit. 11) pada tahapan ini anak mulai menggambar denngan kompleks. Ada variasi pada gambarnya yaitu menggambar rumah ada pohon, orang dan lainnya. 12) mulai muncul garis batas langit, anak mulai mengerti menggambar objek sesuai pada tempatnya dan batas antara langit dan tanah. Pada tahapan 1-5 adalah tahapan untuk anak usia 3-4 tahun, tahapan 5-8 adalah tahapan untuk usia 4-5 tahun, tahapan 9-12 adalah tahapan untuk anak usia 5-7 tahun. Tehnik asesmen yang dilakukan guru berupa checklis sesuai dengan tahapan kemampuan menggambar anak.

\section{b. Kegiatan sholat dhuha}

Kegiatan sholat dhuha adalah kegiatan harian di PAUD MPA Daycare. kegiatan ini diawali dengan berbaris untuk wudhu, tepuk wudhu bersama-sama, membaca niat wudhu kemudian mengantri wudhu. Setelah wudhu siswa berbaris sesuai shaffnya di tempat sholat yang sudah di sediakan. Guru memberikan kesempatan salah satu siswa untuk memimpin sholat. Kegiatan sholat dibimbing oleh guru baik dalam gerakan sholat maupun lafalnya, dalam sholat dhuha siswa juga belajar menghafal QS. Dhuha dan hafalan doa-doa melalui pembiasan setiap hari. Kegiatan sholat dhuha adalah kegiatan mengenalkan tatacara beribadah. 
Dari hasil wawancara dengan guru-guru, perkembangan anak-anak pada kegiatan sholat dhuha berkembang sesuai harapan. Bagi kelas PG dan TK A Anak mampu mengikuti gerakan sholat dengan fokus. Bagi kelas TK B anak mengikuti gerakan sholat dan menirukan bacaan sholat. Pada kegiatan sholat dhuha ada beberapa aspek perkembangan yang dapat dicapai diantaranya: aspek motorik kasar yaitu anak belajar keseimbangan dalam gerakan sholat. Aspek perkembangan nilai agama dan moral yaitu anak menirukan pelaksanaan ibadah sesuai dengan agama yang dianut. Aspek perkembangan kognitif yaitu anak-anak menerapkan pengetahuan dan pengalaman baru melalui menghafal bacaan sholat dan doa melalui pengulangan setiap harinya. Aspek perkembangan sosial emosional yaitu anak belajar mentaati peraturan, sabar menunggu giliran ketika wudhu dan berbagi tempat ketika sholat.

c. Snacktime

Setelah sholat dhuha anak-anak mengantri untuk cuci tangan, kemudian masuk kelas masing-masing untuk kegiatan snacktime. Kegiatan snacktime dimulai dengan baca doa sebelum makan, kemudian guru menginformasikan snack yang akan dibagikan, bahan yang digunakan dalam membuat snack, kandungan gizi, dan manfaatnya. Snack dibagikan secara estafet. Setelah selesai makan snack anak mencuci tangan lalu baca doa setelah makan.

Dari hasil observasi kegiatan snacktime dapat menstimulasi lima aspek perkembangan anak diantaranya: Aspek nilai agama dan moral yaitu anak membaca doa sebelum dan sesudah makan. Anak juga belajar mensyukuri nikmat dengan mengucapkan Alhamdulillah. Aspek perkembangan kognitif nya yaitu anak menambah pengetahuan tentang bahan-bahan makanan, kandungan gizi dan manfaat dari snack yang dibagikan. Aspek perkembangan fisik motoric yang dikembangkan adalah pembiasaan untuk hidup bersih yaitu mencuci tangan sebelum makan. Aspek perkembangan sosial yang dikembangkan adalah sabar menunggu giliran, mengetahui tatacara makan yang baik, dan berbagi dengan teman. Aspek bahasanya yaitu menambah kosakata baru tentang vitamin, bahan-bahan makanan, kandunga dari makanan. Pada wawancara dengan pengelola PAUD MPA Daycare, harapan dari kegiatan ini yaitu anak-anak mendapat pengetahuan dalam memilah makanan yang bermanfaat bagi tubuhnya. Menurut pengelola dari hasil pengamatan, anak-anak sudah mampu memilih makanan yang sehat dan pola pembiasaan dalam kegiatan snacktime sudah berkembang sesuai dengan harapan. 


\section{d. Kegiatan Sentra}

Kegiatan sentra di PAUD MPA Daycare dibagi menjadi tiga yaitu sentra balok, sentra bahan alam dan sentra persiapan. Berdasarkan observasi di sentra bahan alam ada 8 permainan yang disiapkan guru, diantaranya: mengocok sabun, menuang air menggunakan spons, ublek, mencampur warna, klasifikasi batu berwarna, menghitung batu, menumbuk beras dan playdough (Achmadi, 2019). Pada sentra persiapan sudah disiapkan permainan mengenal angka dan huruf menggunakan stempel, puzzle, meronce, menjahit, mengikat tali sepatu, dan balok kereta api (Uswatul Hasanah, 2020). Dari hasil pengamatan pada kegiatan di sentra bahan alam dapat menstimulasi aspek perkembangan yaitu fisik motorik halus, seperti meremas, menuang, menjumput, menumbuk ,memelintir dan mengocok sabun. Aspek perkembangan bahasa yaitu menambah kosakata baru, seperti meleleh, licin, dan lembut. Pada aspek perkembangan kognitif banyak pengetahuan baru yang didapat anak, seperti tekstur, warna, angka dan jumlahnya. Pada Aspek perkembangan seni yaitu membuat kreatifitas dengan playdough. Demikian juga pada sentra persiapan semua aspek perkembangan terstimulasi.

Dari wawancara guru sentra mengatakan, anak-anak suka dan nyaman, ketika bermain di kegiatan sentra. Anak-anak tidak menyadari didalam sentra mereka belajar bukan hanya bermain. Asesmen yang digunakan guru pada kegiatan sentra adalah tehnik pengumpulan data berupa checklis, phortopolio, pengamatan dan wawancara. Tehnik wawancara dilakukan saat anak sedang bermain, guru menggali informasi tentang media yang sedang dimainkan. tehnik checklis dilakukan setelah pembelajaran selesai, hal ini dilakukan untuk mengukur perkembangan anak.

Perkembangan kognitif anak melalui sentra berkembang sesuai harapan, anak-anak mampu membedakan tekstur, menghitung batu 1-20, memisahkan batu berdasarkan warna dan ukuran. nilai agama dan moral anak berkembang dengan baik, hal ini dapat dilihat pembiasaan anak dalam membaca doa sebelum dan sesudah belajar, mengucap kalimat thoyibah, perkembangan motorik halus anak juga terlihat berkembang dengan baik ketika melakukan gerakan meremas spons, membuat bentuk menggunakan media playdough. Aspek fisik motoric kasar berkembang sesuai harapan, anak-anak mampu bergelayut, melompat dan naik pada jaring laba-laba tanpa ada rasa takut. Perkembangan bahasa anak secara reseptif dan 
ekspresif sudah berkembang dengan baik, anak mampu menyimak informasi dari guru. Anakanak juga mampu menjawab pertanyaan dari guru. Untuk perkembangan bahasa secara keaksaraan anak-anak perlu bimbingan lebih dalam lagi. Perkembangan sosial emosional mulai berkembang, anak-anak sudah mampu mengungkapkan ketidak nyamannya ketika di ganggu. Anak berempati ketika temannya bersedih. Perkembangan seni anak sudah mulai muncul, anak mampu berkreatifitas dengan idenya, bernyanyi dan mengikuti gerakan senam dengan baik.

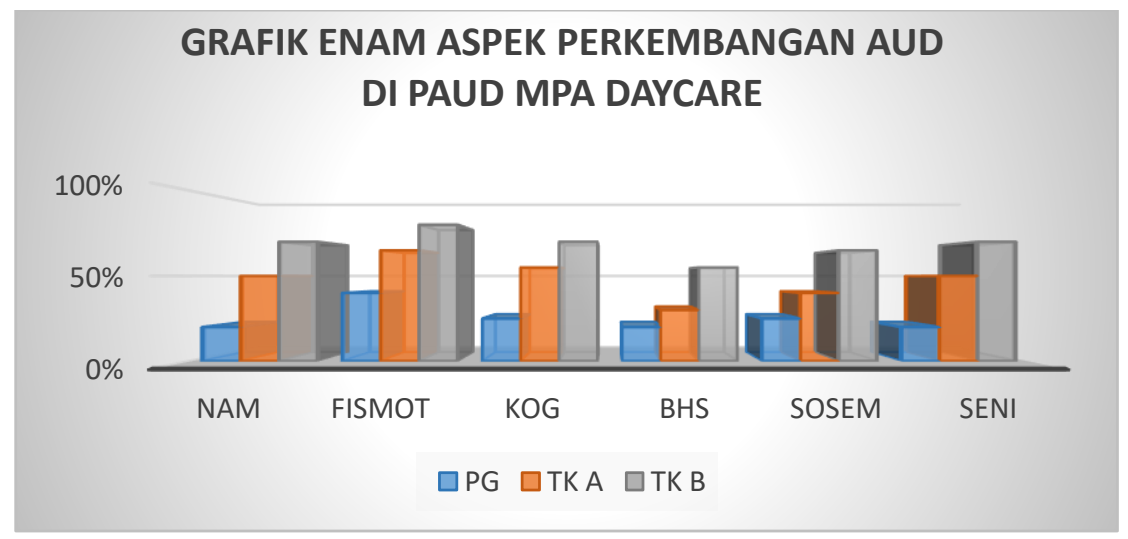

Keterangan:

$$
\begin{array}{ll}
0 \%-20 \% & : \text { Belum muncul } \\
25 \%-40 \% & : \text { Mulai muncul } \\
50 \%-70 \% & : \text { Berkembang sesuai harapan } \\
80 \%-100 \% & : \text { Berkembang sangat baik }
\end{array}
$$

\section{B. Pembahasan}

PAUD MPA Daycare mampu menerapkan nilai agama dan moral sebagai pondasi utama dalam penanaman aqidah. Hasil dari stimulasi yang diberikan dalam pengembangan Nilai Agama dan Moral (NAM) di PAUD MPA Daycare untuk KD mulai berkembang, mau mengikuti doa sebelum dan sesudah melakukan kegiatan, demikian juga kegiatan sholat dhuha walaupun belum fokus karena rentang daya konsentrasi anak masih pendek. Perkembangan NAM anak TK A (RW) mulai berkembang sesuai harapan. Mampu melakukan kegiatan hafalan hadits, QS. At Taubah dan hafalan doa dengan lancar, namun untuk kegiatan sholat dhuha perlu bimbingan (Kusnilawati et al., 2018). Hasil stimulasi anak 
TK B (RF) berkembang dengan baik, mampu melakukan sholat dhuha dengan fokus, hafalan doa, hadits dan QS. At Taubah sudah lancar. Dari keterangan diatas dapat disimpulkan bahwa asesmen di PAUD MPA Daycare sesuai dengan teori Akmal(2018) dalam jurnal Lestari(2020) yang menyatakan bahwa agama merupakan pijakan utama bagi manusia yang berperan penting dalam menapaki hidup selanjutnya, Agama menjadi pondasi utama bagi anak dalam menghadapi tantangan hidupnya.

Hasil penelitian di PAUD MPA Daycare terlihat mampu mengakomodasi perkembangan fisik motorik anak, dengan menyiapkan arena bermain yang memfasilitasi anak dalam gerakan bergelayut, melompat, merunduk dan merayap jaring laba-laba, serta kegiatan senam pagi. Hasil stimulasi anak PG, TK A dan TK B berkembang dengan baik. Hal ini dipengaruhi oleh fasililitas dan waktu yang sudah di berikan oleh sekolah dan juga lingkungan yaitu masih banyak kebun yang ada disekitar rumahnya. Demikian juga pada fisik motorik halus, stimulasi diberikan pada kegiatan jurnal dan sentra, sehingga anak mampu melakukan gerakan menjumput, memelintir, meremas, menggunting sebagai persiapan menulis awal. Dari hasil jurnal anak-anak terlihat kemampuan menulis awal dan menggambar sudah berkembang sesuai harapan. Pada hasil penelitian diatas terhadap perkembangan fisik motorik anak di PAUD MPA Daycare sesuai penelitian yang dilakukan Indraswari:2012 yang menyatakan bahwa ketrampilan motorik halus merupakan suatu pengorganisasian antara otot kecil seperti jari dan tangan, mata dan akurasi visual/mata.

Perkembangan kognitif di PAUD MPA Daycare berkembang dengan baik, sesuai tahapan usia anak. Dari hasil stimulasi yang diberikan anak-anak sudah menunjukan pola perkembangan kognitif yang baik. Anak PG sudah mampu menceritakan tentang kegiatan yang dilakukannya, serta mampu menceritakan tentang hasil karyanya (Komalasari, 2014). Pada perkembangan anak TK A (RW) mampu mengatasi konflik dengan temannya dan mampu menggunakan alat berdasrkan fungsinya. Dilihat dari hasil jurnal, dapat menggambar sesuai bentuk, berhitung 1-20 dan mengenal abjad. Perkembangan kognitif anak TK B (RF) sudah berkembang dengan baik. Terlihat dari hasil stimulasi mampu menyusun kepingan puzzle dengan baik, mengenal jumlah dan angka, mmengurutkan pola ABCD dalam kegiatan meronce. Merujuk dari teori J.Piaget yang menyatakan bahwa anak usia 2-7 tahun adalah tahap pemikiran pra-operasional, dimana anak harus belajar dari mengembangkan daya ingat dan berpikir simbolik (Arifiyanti,2020). 
Pada anak usia 2-6 tahun mencapai 3000 kosakata yang di ucapkan anak. Perkembangan bahasa anak di PAUD MPA Daycare sudah berkembang sesuai dengan teori Lundsteen, seperti kemampuan berbahasa KW yang mampu mengucapkan 2000-4000 kata, RW yang mampu melapor hasil jurnal dan kegiatannya dan RF yang dapat melanjutkan sebagian cerita ketika guru mendongeng. Perkembahasa reseptif anak dan ekspresif anak berkembang dengan baik, namun dalam perkembangan bahasa keaksaraan perlu dukungan yang lebih sehingga perkembangan bahasa anak dapat berkembang secara optimal. Perkembangan bahasa anak berkaitan erat dengan perkembangan kognitif, hal ini berdasarkan dari penelitian Goldin-Meadow,S. Et. Al.(2014) yang menyatakan adanya peningkatan bahasa dan perkembangan kognitif pada anak.

Perkembangan sosial emosional di PAUD MPA Daycare sudah berkembang sesuai harapan. Terlihat pada perkembangan sosial emosional KW yang berada dilingkungan keluarga yang baik, sehingga terbentuk sikap mandiri dan sikap prososial dalam bergaul dengan temannya. Perkembangan sosial emosional RW (TK A) sudah berkembang dengan baik, sehingga mampu bekerja sama dalam suatu kelompok, mampu bersabar menunggu giliran ketika mengantri wudhu, dan dapat membantu teman dalam menyelesaikan permainannya (Kusdiyati et al., 2012). Perkembangan sosial RF (TK B) mulai berkembang namun tahapan dalam menyelesaikan masalah baru mampu menggunakan fisik, belum mampu mengontrol geraknya dalam memukul, mendorong teman. perkembangan sosial emosional yang baik menjadi pondasi bagi anak dalam bergaul dengan sesama dan belajar yang lebih baik dalam beraktifitas di lingkungannya (Khasanah et al., 2012).

Aspek perkembangan seni pada PAUD MPA Daycare terlihat pada kegiatan awal pembelajaran sebagai transisi lingkungan rumah ke lingkungan sekolah, sehingga anak dapat beradaptasi di lingkungan yang baru. Halimah berpendapat bahwa musik adalah cara untuk melepaskan serta mengekspresikan perasaan seseorang dalam suasana hati maupun emosi (Halimah, 2017). Aspek seni juga diharapkan menjadi proses aktualisasi bagi anak dalam mengekspresikan kemampuan kreativitasnya.

\section{SIMPULAN DAN SARAN}

hasil analisis data melalui observasi/pengamatan dan wawancara secara keseluruhan, pelaksanaan asesmen di PAUD MPA Daycare, Karawang di lakukan dengan baik sehingga 
dapat mendeteksi tingkat pencapaian perkembangan anak, sehingga kurikulum pembelajaran 2013 mampu dikembangkan dengan baik. Hal ini dibuktikan dari ketiga anak yang menjadi sampel mewakili usianya berkembang sesuai tahapan perkembangannya secara optimal. Setiap kegiatan pembelajaran di sekolah tersebut dapat menstimulus semua aspek perkembangan anak, baik dalam kegiatan pijakan lingkungan, kegiatan awal pembelajaran, jurnal pagi, kegiatan sholat dhuha, kegiatan snacktime bermain bebas dan kegiatan sentra. Anak sudah mampu mengikuti kegiatan pembelajaran dengan tertib sesuai dengan jadwal pembelajaran.

Beberapa saran yang akan disampaikan oleh peneliti yang pertama untuk pengelola PAUD MPA Daycare diharapkan lebih menggali lagi kegiatan literasi pada anak karena dari hasil asessment tampak belum berkembang secara maksimal . Hal ini berdampak pada kurang berkembangnya keaksaraan anak. Mengingat pentingnya literasi untuk pendidikan dasar maka alangkah baiknya jika ditambahkan sudut literasi dalam setiap kegiatan pembelajaran.

\section{UCAPAN TERIMA KASIH}

Puji syukur kehadirat Allah SWT karena berkat rahmatNyalah penelitian dapat diselesaikan. Ucapan terima kasih juga penulis sampaikan kepada Ibu Ine Nirmala, S.Pd, M.Pd selaku Kepala Prodi Pendidikan Islam Anak Usia Dini. Yang kedua ucapan terimakasih kepada Ibu Rina Syafrida, S.Pd., M.Pd dan Ibu Hj Debibik Nabilah Fauziyah, Lc, M.PdI selaku Dosen Pembimbing yang telah meluangkan waktunya untuk membimbing saya dalam penelitian kali ini. Tim Jurnal Al Athfaal yang telah memberi kesempatan kepada penulis untuk menerbitkan artikelnya. Selanjutnya ucapan terimakasih juga saya ucapkan kepada Ibu Hjh Hidayatul Karomah selaku Pengelola PAUD MPA Daycare yang telah memberikan kesempatan untuk melakukan penelitan di sekolah yang dipimpinnya. Dan yang terahir ucapan terimakasih ditujukan kepada Bunda-bunda pengajar PAUD MPA Daycare dan murid-murid dari PAUD MPA Daycare yang telah membantu dalam proses penelitian kali ini. Semoga tulisan ini dapat menjadi motivasi bagi para pendidik dalam melakukan asesmen.

\section{DAFTAR PUSTAKA}

Achmadi, A. (2019). Model Pembelajaran Sentra Dapat Mengembangkan Sikap Bersosial Untuk Anak Usia Taman Kanak Kanak. Incrementapedia: Jurnal Pendidikan Anak Usia Dini, 1(02), 26-31. https://doi.org/10.36456/incrementapedia.vol1.no02.a2090 
Adhimah, S. (2020). Peran Orang Tua Dalam Menghilangkan Rasa Canggung Anak Usia Dini (Studi Kasus Di Desa Karangbong RT. 06 RW. 02 Gedangan-Sidoarjo). Jurnal Pendidikan Anak, 9(1), 57-62. https://doi.org/10.21831/jpa.v9i1.31618

Amalia, I. A. (2016). Aspek Perkembangan Motorik Dan Hubungannya Dengan Aspek Fisik Dan Intelektual Anak. Awlady: Jurnal Pendidikan Anak, 2(1), 1-12. https://doi.org/10.24235/awlady.v2i1.760

Astuti, W. P., Prasetyo, A. P. B., \& Rahayu, E. S. (2012). Pengembangan Instrumen Asesmen Autentik Berbasis Literasi Sains Pada Materi Sistem Ekskresi. Lembaran Ilmu Kependidikan, 41(1).

Damayanti, E., Hartika, A. S., Sanusi, L., Jannah, R., \& Pratiwi, S. I. (2018). Manajemen Penilaian Pendidikan Anak Usia Dini. Indonesian Journal of Early Childhood Education, 1(1), 13-24.

Erlianda, T., Fauzi, A., \& Amri, K. (2019). Meningkatkan Kemampuan Motorik Halus Anak melalui Kegiatan Menulis di Atas Pasir. Attāalunā: Journal of Islamic Early Childhood Education, 2(2), 74-85. https://doi.org/10.32505/atfaluna.v2i2.1336

Halimah, L. (2017). Musik Dalam Pembelajaran. Jurnal Eduhumaniora, 2(2), 1-19. https://doi.org/DOI: https://doi.org/10.17509/eh.v2i2.2763

Ine Nirmala dan Feronica Eka Putri. (2015). 1039-2900-1-Sm. Pendidikan Pascasarjana Magister PAI, 2(1), 125-144.

Jatmiko, A. J., Hadiati, E. H., \& Oktavia, M. O. (2020). Penerapan Evaluasi Pembelajaran Anak Usia Dini di Taman Kanak-kanan. Al-Athfaal: Jurnal Ilmiah Pendidikan Anak Usia Dini, 3(1), 83-97. https://doi.org/10.24042/ajipaud.v3i1.6875

Khadijah, K., \& Amelia, N. (2020). Asesmen Perkembangan Kognitif Anak Usia 5-6 Tahun. Al-Athfaal: Jurnal Ilmiah Pendidikan Anak Usia Dini, 3(1), 69-82. https://doi.org/10.24042/ajipaud.v3i1.6508

Khasanah, I., Prasetyo, A., \& Rakhmawati, E. (2012). Permainan Tradisional Sebagai Media Stimulasi Aspek Perkembangan Anak Usia Dini. PAUDIA: Jurnal Penelitian Dalam Bidang Pendidikan Anak Usia Dini, 1(1). https://doi.org/10.26877/paudia.v1i1.261

Komalasari, R. (2014). Domain Fungsi Kognitif Setelah Terapi Stimulasi Kognitif. Jurnal Keperawatan Indonesia, 17(1), 11-17. https://doi.org/10.7454/jki.v17i1.372

Kusdiyati, S., Ma'arif, B. S., \& Rahayu, M. S. (2012). Hubungan Antara Intensitas Dzikir Dengan Kecerdasan Emosional. MIMBAR, Jurnal Sosial Dan Pembangunan, 28(1), 31. https://doi.org/10.29313/mimbar.v28i1.336

Kusnilawati, K., Fauziddin, M., \& Astuti, A. (2018). Meningkatkan Aspek Perkembangan Nilai Agama Dan Moral Anak Usia Dini Dengan Penerapan Metode Bercerita Tema Islami. Aulad: Journal on Early Childhood, 1(1), 28-38. https://doi.org/10.31004/aulad.v1i1.4

Nugraha, B. (2015). Pendidikan Jasmani Olahraga Usia Dini. Jurnal Pendidikan Anak, 4(1), 557-564. https://doi.org/10.21831/jpa.v4i1.12344

Nur, L., Hafina, A., \& Rusmana, N. (2020). Kemampuan Kognitif Anak Usia Dini Dalam Pembelajaran Akuatik. Scholaria: Jurnal Pendidikan Dan Kebudayaan, 10(1), 42-50. 
https://doi.org/10.24246/j.js.2020.v10.i1.p42-50

Prihanjani, N. L., Wirya2, I. N., \& Tirtayani3, L. A. (2017). Kemampuan Berbicara Anak Kelompok A Gugus IV Kecamatan Buleleng Jurusan Pendidikan Guru Pendidikan Anak Usia Dini Fakultas Ilmu Pendidikan Universitas Pendidikan Ganesha e-Journal Pendidikan Anak Usia Dini Universitas Pendidikan Ganesha. 5(2), 231-240.

Sari, R. P. (2013). Kegiatan Bermain Matematika. Jurnal Pendidikan Usia Dini, 7(2), $263-$ 275.

Saripudin, A., \& Awelas, T. A. (2020). Classroom Assesmen Pada Aspek Perkembangan Nilai Agama Dan Moral Di Tkit Al-Ikhlas Al-Ma'Arif Cirebon. AWLADY: Jurnal Pendidikan Anak, 6(2), 313. https://doi.org/10.24235/awlady.v6i2.7230

Syafrida, R., Rahayu, E. T., Karyawati, L., \& Permana, H. (2020). Inovasi media CB Hoop pada aktifitas motorik kasar Anak selama Belajar Dari Rumah. 5(2), 85-96.

Uswatul Hasanah. (2020). Implementasi Sentra Bermain Peran Dalam Pembelajaran Bahasa Anak Di Paud Al Amin Pringgodani Bantur-Malang. JURALIANSI: Jurnal Lingkup Anak Usia Dini, 1(2), 60-67. https://doi.org/10.35897/juraliansipiaud.v1i2.364

Wijaya Kuswanto, C., \& Dinda Pratiwi, D. (2020). Pengembangan Bahan Ajar Pendidikan Jasmani untuk Anak Usia Dini Berbasis Tematik (Development of Thematic-Based Physical Education Teaching Materials for Early Childhood). Al-Athfal: Jurnal Pendidikan Anak, 6(1), 55-68. https://doi.org/10.14421/al-athfal.2020.61-05

Wiresti, R. D. (2021). Analisis Aspek Perkembangan Kognitif Dan Motorik Dalam Permainan Jump Count Melalui Abacus Tangga. 7(1), 134-147.

Wiyani, N. A. (2019). Strategi Kemitraan Penyelenggaraan Parenting Bagi Orang Tua di Lembaga PAUD Kecamatan Bumiayu Kabupaten Brebes. Dimas: Jurnal Pemikiran Agama Untuk Pemberdayaan, 19(2), 143. https://doi.org/10.21580/dms.2019.192.4354

Yuningsih, A., \& Hasanah, U. (2018). Penggunaan Playdogh Dalam Mengembangkan Motorik Halus. Al-Athfaal: Jurnal Ilmiah Pendidikan Anak Usia Dini, 1(1), 117-128. https://doi.org/10.24042/ajipaud.v1i1.3408 